Supplement of Hydrol. Earth Syst. Sci., 25, 3071-3086, 2021

https://doi.org/10.5194/hess-25-3071-2021-supplement

(c) Author(s) 2021. CC BY 4.0 License.

(c) (i)

Supplement of

\title{
River runoff in Switzerland in a changing climate - runoff regime changes and their time of emergence
}

Regula Muelchi et al.

Correspondence to: Regula Muelchi (regula.muelchi@giub.unibe.ch)

The copyright of individual parts of the supplement might differ from the article licence. 
Table S1: Overview of the main characteristics of the 93 catchments

\begin{tabular}{|c|c|c|c|c|c|c|c|}
\hline 目 & 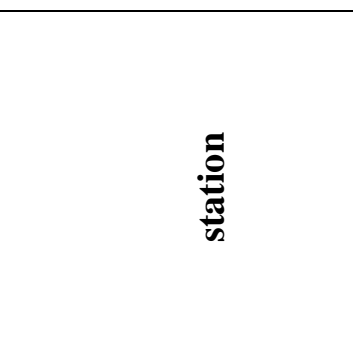 & $\stackrel{\grave{d}}{:}$ & 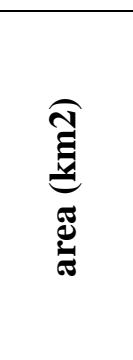 & 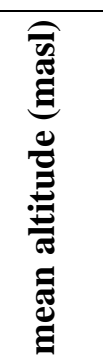 & 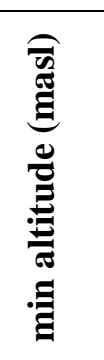 & 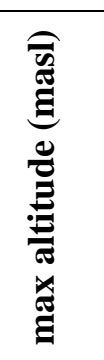 & 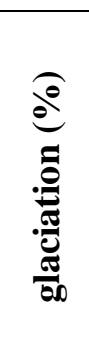 \\
\hline 2020 & Bellinzona & Ticino & 1517.5 & 1679 & 220 & 3345 & 0 \\
\hline 2033 & Ilanz & Vorderrhein & 774 & 2026 & 685 & 3557 & 1.8 \\
\hline 2034 & Payerne & Broye & 415.9 & 724 & 368 & 1574 & 0 \\
\hline 2044 & Andelfingen & Thur & 1701.6 & 773 & 354 & 2431 & 0 \\
\hline 2056 & Seedorf & Reuss & 833.2 & 2005 & 432 & 3598 & 6.4 \\
\hline 2070 & Emmenmatt & Emme & 443 & 1072 & 562 & 2161 & 0 \\
\hline 2078 & Le Prese & Poschiavino & 167.7 & 2161 & 962 & 3875 & 3.9 \\
\hline 2084 & Ingenbohl & Muota & 316.6 & 1364 & 425 & 2731 & 0 \\
\hline 2087 & Andermatt & Reuss & 190.2 & 2276 & 1125 & 3598 & 2.9 \\
\hline 2104 & Weesen & Linth & 1061.5 & 1580 & 416 & 3557 & 1.6 \\
\hline 2106 & Muenchenstein & Birs & 887.3 & 733 & 256 & 1424 & 0 \\
\hline 2112 & Appenzell & Sitter & 74.4 & 1254 & 445 & 2431 & 0 \\
\hline 2122 & Moutier & Birse & 185.8 & 927 & 493 & 1424 & 0 \\
\hline 2126 & Waengi & Murg & 80.1 & 654 & 456 & 1113 & 0 \\
\hline 2132 & Neftenbach & Toess & 343.3 & 659 & 380 & 1298 & 0 \\
\hline 2141 & Tiefencastel & Albula & 529 & 2127 & 837 & 3317 & 0.5 \\
\hline 2151 & Oberwil & Simme & 343.7 & 1639 & 778 & 3208 & 2.4 \\
\hline 2155 & Wiler & Emme & 924.1 & 871 & 430 & 2161 & 0 \\
\hline 2159 & Belp & Guerbe & 116.1 & 849 & 508 & 2128 & 0 \\
\hline 2160 & Broc & Sarine & 636.3 & 1501 & 674 & 3207 & 0 \\
\hline 2167 & Ponte Tresa & Tresa & 609.1 & 805 & 198 & 2207 & 0 \\
\hline 2176 & Zuerich & Sihl & 342.6 & 1047 & 402 & 2223 & 0 \\
\hline 2179 & Thoerishaus & Sense & 351.2 & 1076 & 524 & 2182 & 0 \\
\hline 2181 & Halden & Thur & 1085 & 914 & 445 & 2431 & 0 \\
\hline 2185 & Chur & Plessur & 264.4 & 1865 & 545 & 2923 & 0 \\
\hline 2202 & Liestal & Ergolz & 261.2 & 591 & 296 & 1181 & 0 \\
\hline 2203 & Aigle & Grande Eau & 131.6 & 1566 & 384 & 3167 & 0.8 \\
\hline 2210 & Ocourt & Doubs & 1275.4 & 960 & 407 & 1448 & 0 \\
\hline 2219 & Oberried & Simme & 34.7 & 2335 & 1075 & 3208 & 22.6 \\
\hline 2232 & Adelboden & Allenbach & 28.8 & 1855 & 1093 & 2833 & 0 \\
\hline 2256 & Pontresina & Rosegbach & 66.5 & 2701 & 1720 & 3981 & 21.7 \\
\hline 2262 & Pontresina & Berninabach & 106.9 & 2608 & 1783 & 3981 & 14.4 \\
\hline 2270 & Combe des Sarrasins & Doubs & 998.5 & 985 & 553 & 1448 & 0 \\
\hline 2276 & Isenthal & Grosstalbach & 43.9 & 1810 & 767 & 2961 & 6.7 \\
\hline 2299 & Erstfeld & Alpbach & 20.7 & 2181 & 629 & 3129 & 19.7 \\
\hline 2300 & Euthal & Minster & 59.1 & 1352 & 642 & 2223 & 0 \\
\hline 2303 & Jonschwil & Thur & 492.9 & 1027 & 535 & 2431 & 0 \\
\hline 2304 & Zernez & Ova dal Fuorn & 55.3 & 2333 & 1666 & 3114 & 0 \\
\hline 2305 & Herisau & Glatt & 16.7 & 836 & 624 & 1145 & 0 \\
\hline
\end{tabular}




\begin{tabular}{|c|c|c|c|c|c|c|c|}
\hline 2307 & Sonceboz & Suze & 127.2 & 1044 & 634 & 1595 & 0 \\
\hline 2308 & Goldach & Goldach & 50.4 & 840 & 391 & 1245 & 0 \\
\hline 2312 & Salmsach & Aach & 47.4 & 476 & 391 & 609 & 0 \\
\hline 2319 & Zernez & Ova da Cluozza & 26.9 & 2361 & 1468 & 3115 & 0 \\
\hline 2321 & Pregassona & Cassarate & 75.8 & 991 & 272 & 2198 & 0 \\
\hline 2342 & Brig & Saltina & 76.5 & 2017 & 661 & 3407 & 2.5 \\
\hline 2343 & Huttwil & Langeten & 59.9 & 765 & 566 & 1123 & 0 \\
\hline 2355 & Davos & Landwasser & 183.7 & 2223 & 1453 & 3180 & 0 \\
\hline 2356 & Cavergno & Riale di Calneggia & 23.9 & 1982 & 645 & 2866 & 0 \\
\hline 2366 & La Roesa & Poschiavino & 14.1 & 2286 & 1707 & 3012 & 0 \\
\hline 2368 & Locarno & Maggia & 926.9 & 1534 & 191 & 3208 & 0 \\
\hline 2369 & Yvonand & Mentue & 105.3 & 683 & 436 & 946 & 0 \\
\hline 2370 & Le Noirmont & Doubs & 1046.7 & 985 & 503 & 1448 & 0 \\
\hline 2372 & Mollis & Linth & 600.2 & 1737 & 427 & 3557 & 2.9 \\
\hline 2374 & Mogelsberg & Necker & 88.1 & 962 & 604 & 1513 & 0 \\
\hline 2386 & Frauenfeld & Murg & 213.3 & 596 & 381 & 1113 & 0 \\
\hline 2409 & Eggiwil & Emme & 124.4 & 1283 & 562 & 2161 & 0 \\
\hline 2412 & Vuippens & Sionge & 43.4 & 872 & 674 & 1457 & 0 \\
\hline 2415 & Rheinsfelden & Glatt & 417.4 & 506 & 340 & 1105 & 0 \\
\hline 2419 & Reckingen & Rhone & 214.3 & 2301 & 1307 & 3598 & 11.8 \\
\hline 2420 & Lumino & Moesa & 471.9 & 1668 & 229 & 3169 & 0 \\
\hline 2426 & Mels & Seez & 106.1 & 1796 & 469 & 3073 & 0 \\
\hline 2432 & Ecublens & Venoge & 227.6 & 694 & 372 & 1662 & 0 \\
\hline 2434 & Olten & Duennern & 233.8 & 714 & 390 & 1383 & 0 \\
\hline 2450 & Zofingen & Wigger & 366.2 & 662 & 419 & 1393 & 0 \\
\hline 2461 & Magliaso & Magliasina & 34.4 & 927 & 269 & 1904 & 0 \\
\hline 2468 & St. Gallen & Sitter & 261.1 & 1045 & 445 & 2431 & 0 \\
\hline 2469 & Hondrich & Kander & 490.7 & 1846 & 558 & 3675 & 5.1 \\
\hline 2471 & Murgenthal & Murg & 183.4 & 659 & 410 & 1123 & 0 \\
\hline 2474 & Buseno & Calancasca & 120.5 & 1930 & 503 & 3169 & 0.2 \\
\hline 2477 & Zug & Lorze & 100.2 & 822 & 411 & 1556 & 0 \\
\hline 2478 & Soyhieres & Birse & 569.5 & 811 & 380 & 1424 & 0 \\
\hline 2479 & Delemont & Sorne & 213.9 & 785 & 408 & 1326 & 0 \\
\hline 2480 & Boudry & Areuse & 377.7 & 1084 & 427 & 1573 & 0 \\
\hline 2481 & Buochs & Engelberger Aa & 228 & 1605 & 432 & 3137 & 2.5 \\
\hline 2486 & Vevey & Veveyse & 64.5 & 1108 & 372 & 1959 & 0 \\
\hline 2487 & Werthenstein & Kleine Emme & 311.5 & 1171 & 525 & 2290 & 0 \\
\hline 2491 & Buerglen & Schaechen & 107.9 & 1722 & 436 & 3221 & 1.5 \\
\hline 2493 & Gland & Promenthouse & 119.8 & 1035 & 372 & 1667 & 0 \\
\hline 2494 & Pollegio & Ticino & 443.8 & 1794 & 277 & 3120 & 0 \\
\hline 2497 & Nebikon & Luthern & 104.7 & 754 & 474 & 1393 & 0 \\
\hline 2498 & Castrisch & Glenner & 380.9 & 2014 & 685 & 3345 & 1.1 \\
\hline 2500 & Ittigen & Worble & 67.1 & 678 & 494 & 954 & 0 \\
\hline 2603 & Langnau & Ilfis & 187.4 & 1047 & 681 & 2045 & 0 \\
\hline 2604 & Biberbrugg & Biber & 31.9 & 1008 & 602 & 1515 & 0 \\
\hline 2605 & Lavertezzo & Verzasca & 185.1 & 1663 & 463 & 2837 & 0 \\
\hline 2607 & Oberwald & Goneri & 38.4 & 2378 & 1353 & 3120 & 4 \\
\hline
\end{tabular}




\begin{tabular}{|l|l|l|r|r|r|r|r|}
2609 & Einsiedeln & Alp & 46.7 & 1161 & 660 & 1783 & 0 \\
\hline 2610 & Vicques & Scheulte & 72.7 & 797 & 419 & 1292 & 0 \\
\hline 2612 & Lavertezzo & Riale di Pincascia & 44.5 & 1713 & 463 & 2520 & 0 \\
\hline 2617 & Muestair & Rom & 128.5 & 2188 & 1167 & 3196 & 0 \\
\hline 2629 & Agno & Vedeggio & 99.9 & 921 & 198 & 2198 & 0 \\
\hline 2630 & Sion & Sionne & 27.6 & 1575 & 485 & 3084 & 0 \\
\hline 2634 & Emmen & Kleine Emme & 478.3 & 1058 & 425 & 2290 & 0 \\
\hline
\end{tabular}




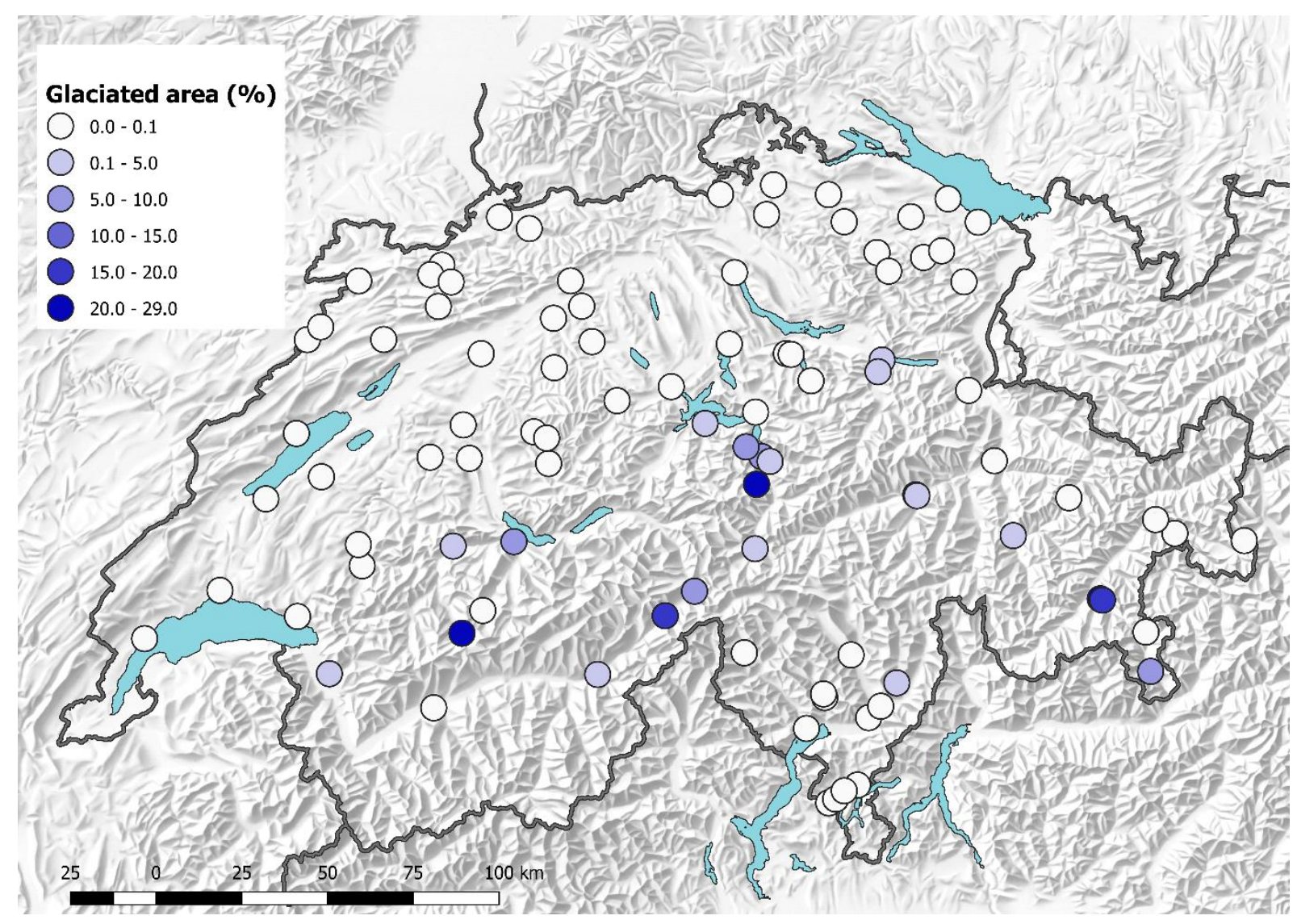

Figure S1: Degree of modelled glaciated area in the reference period. 


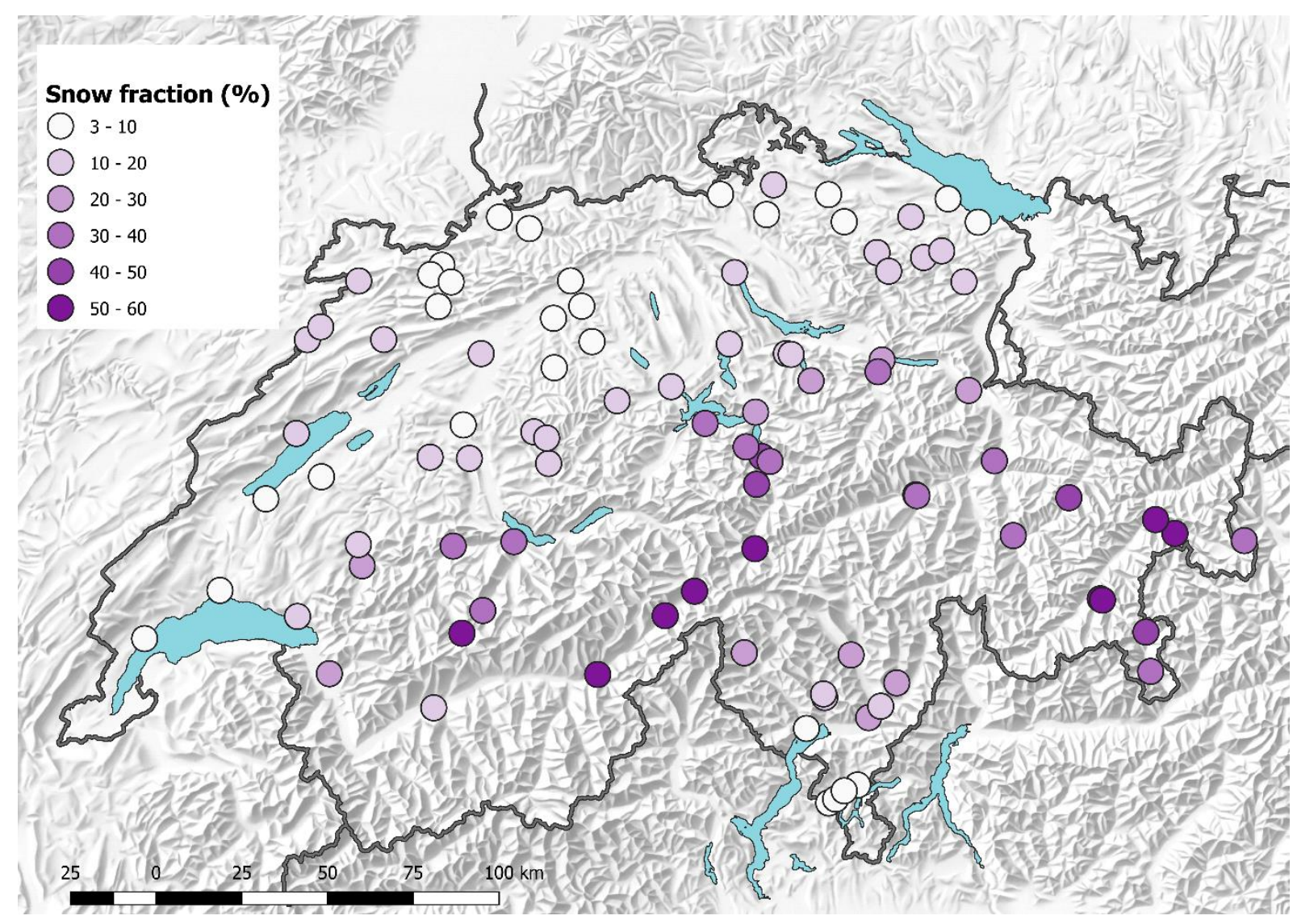

Figure S2: Median of modelled fraction of annual precipitation falling as snow in the reference period. 
(a)

DJF

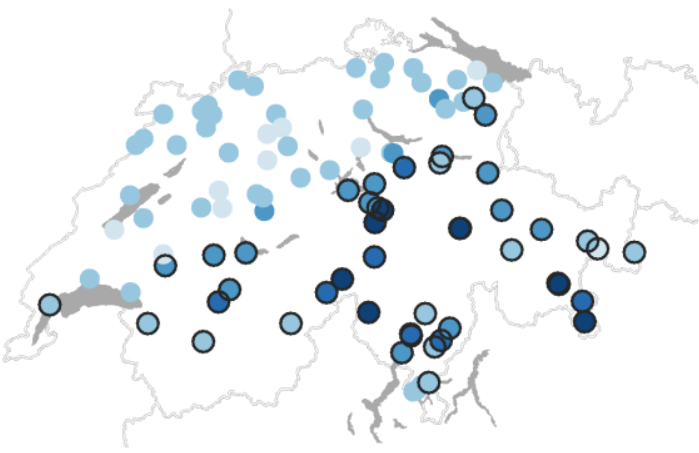

(c)

JJA

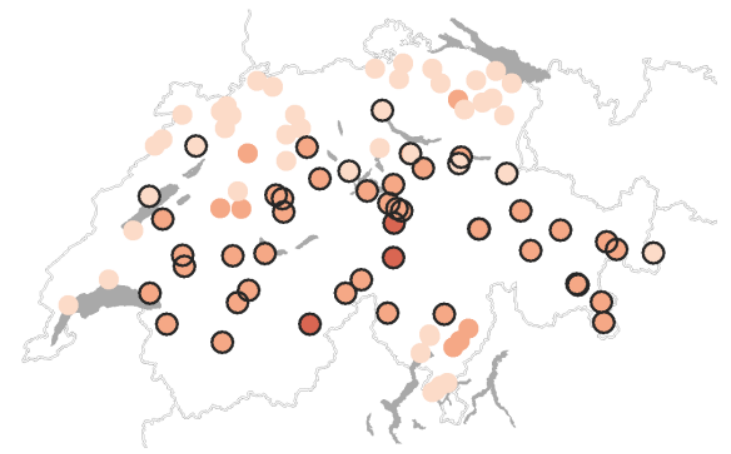

(e)

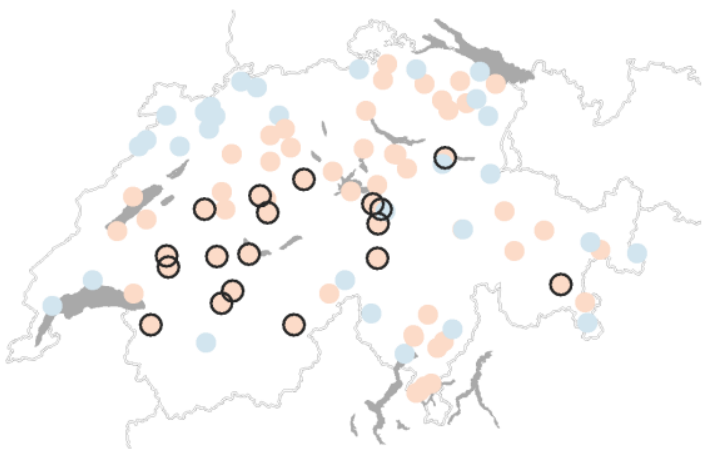

(b)

MAM

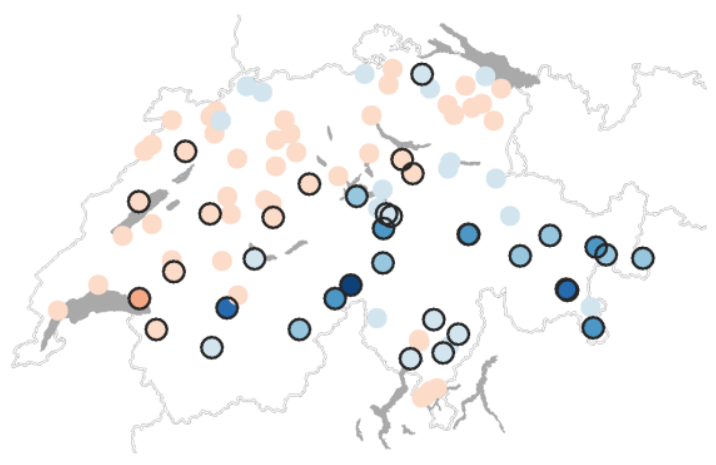

(d)

SON

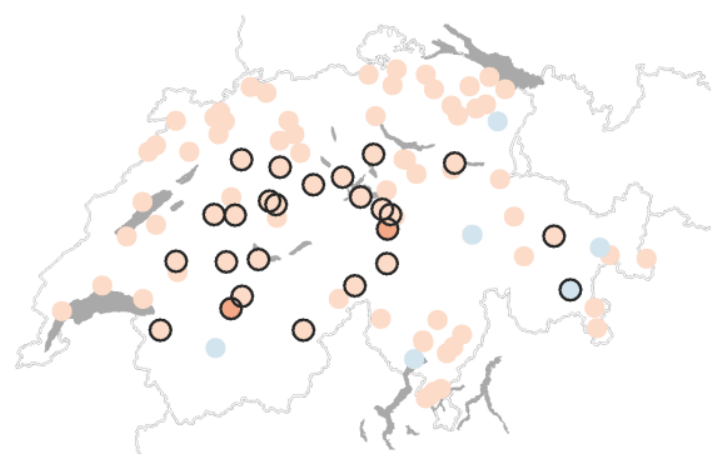

(\%)

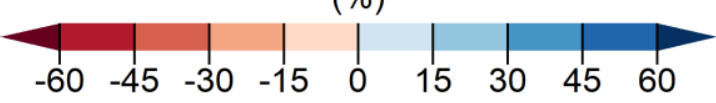

Figure S3: Multimodel median of seasonal and annual mean changes of runoff under RCP4.5 by 2070-2099 for winter (a), spring (b), summer (c), autumn (d), and annual means (e). Black circles indicate catchments whose direction of change agrees across at least $90 \%$ the models. 
(a)

DJF

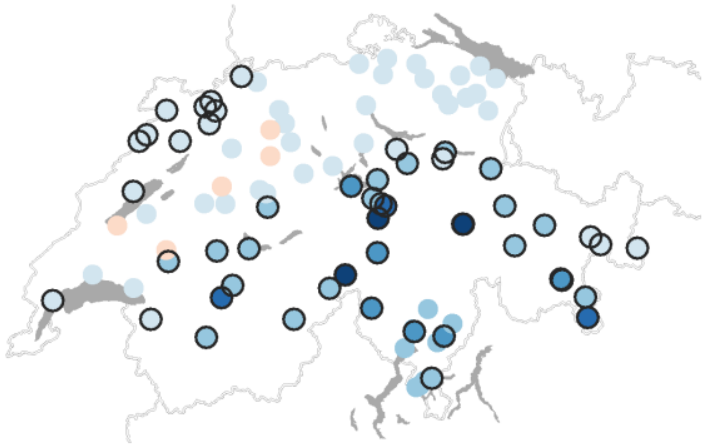

(c)

JJA

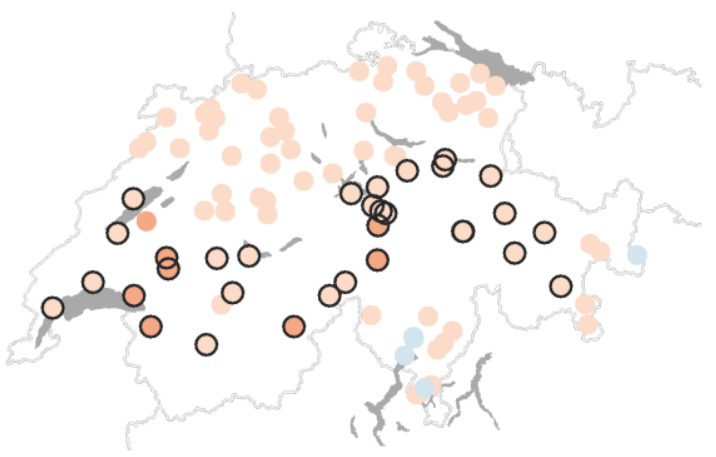

(e)

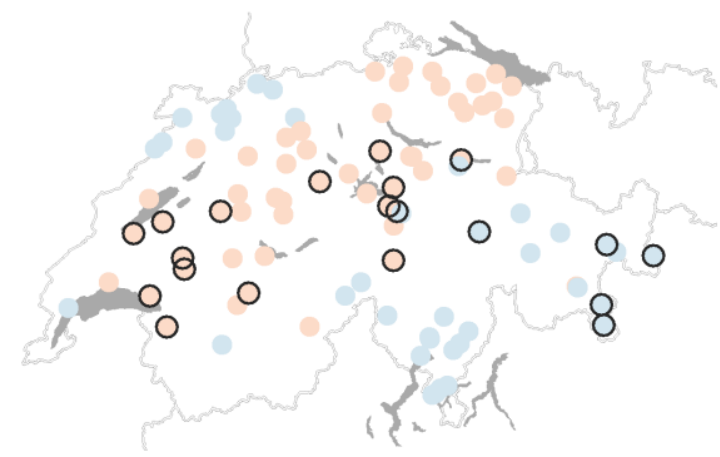

(b)

MAM

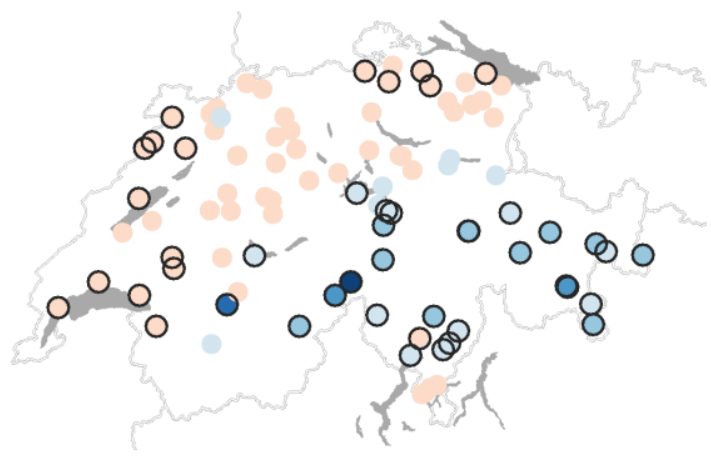

(d)

SON

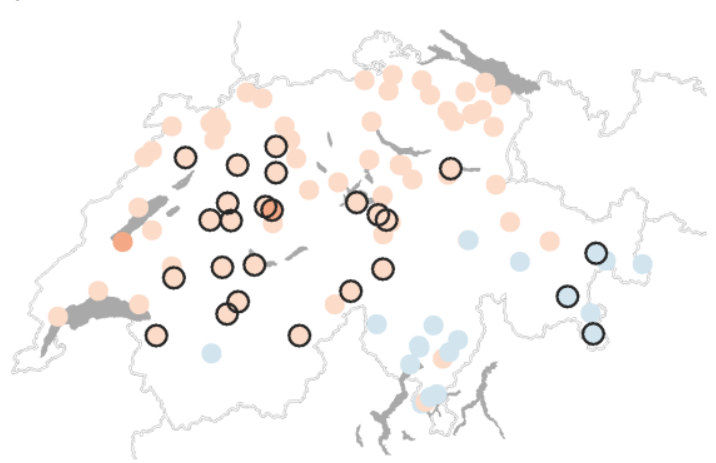

(\%)

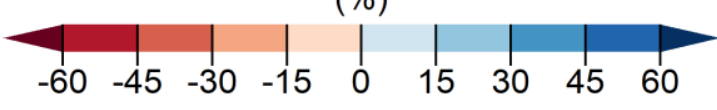

Figure S4: Multimodel median of seasonal and annual mean changes of runoff under RCP2.6 by 2045-2074 for winter (a), spring (b), summer (c), autumn (d), and annual means (e). Black circles indicate catchments whose direction of change agrees across at least $90 \%$ the models. 
(a)

DJF

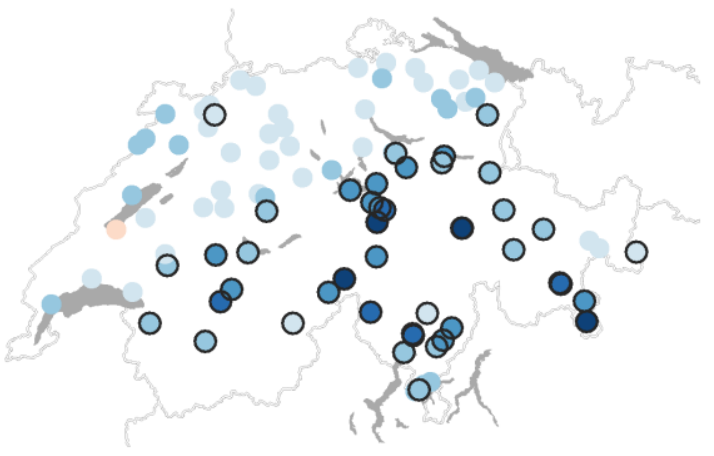

(c)

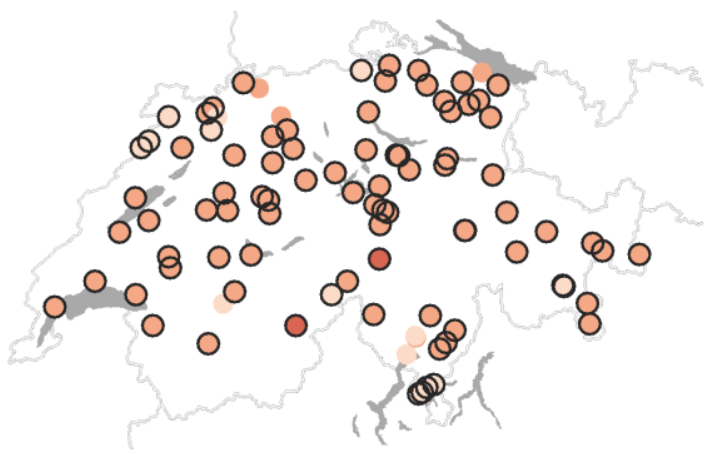

(e)

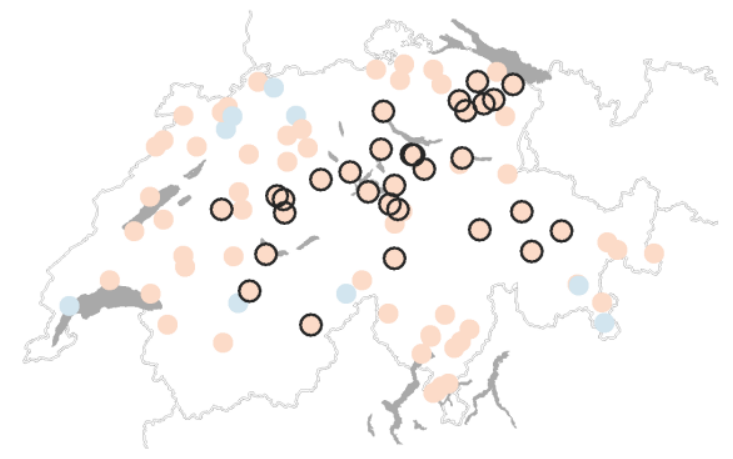

(b)

MAM

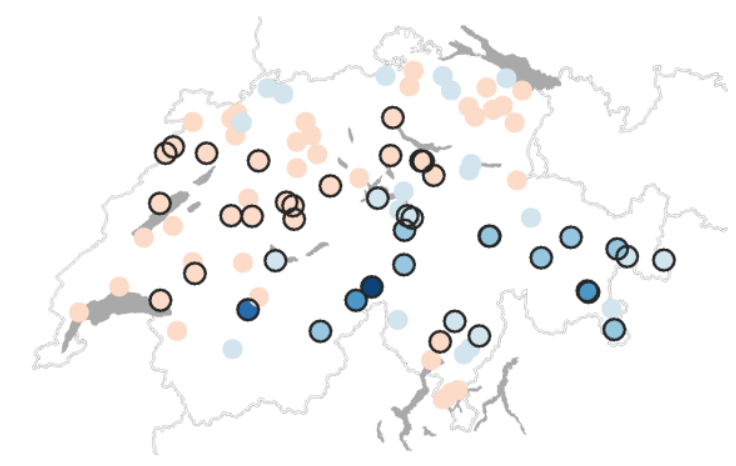

(d)

SON

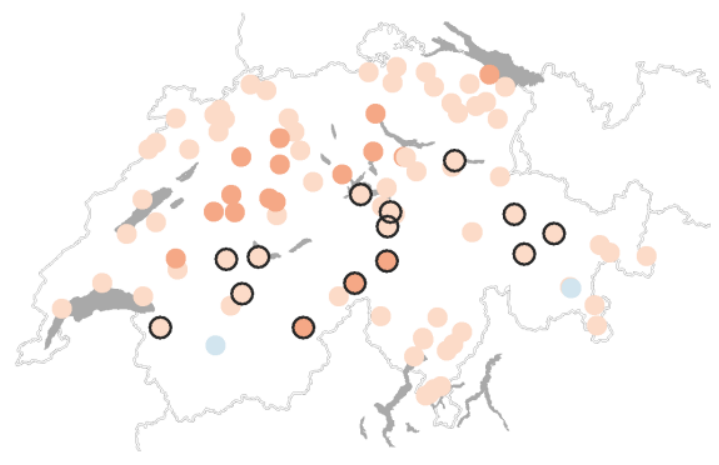

(\%)

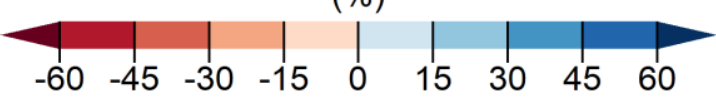

Figure S5: Multimodel median of seasonal and annual mean changes of runoff under RCP4.5 by 2045-2074 for winter (a), spring (b), summer (c), autumn (d), and annual means (e). Black circles indicate catchments whose direction of change agrees across at least $90 \%$ the models. 
(a)

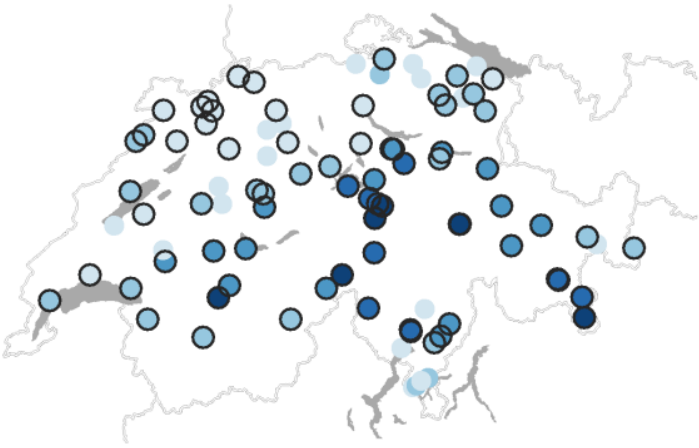

(c)

$$
\text { JJA }
$$

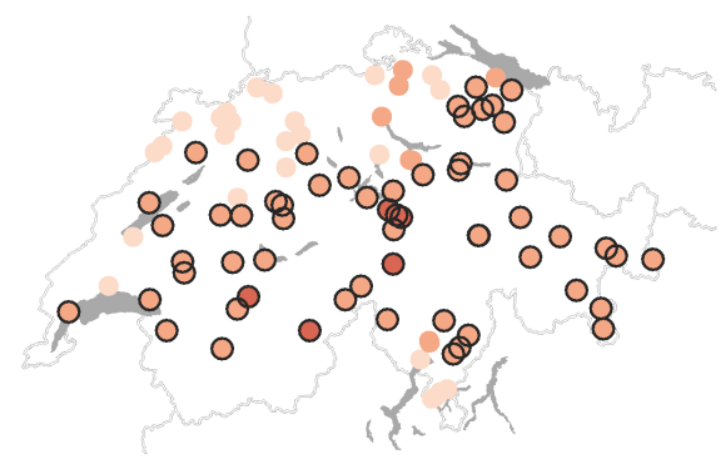

(e)

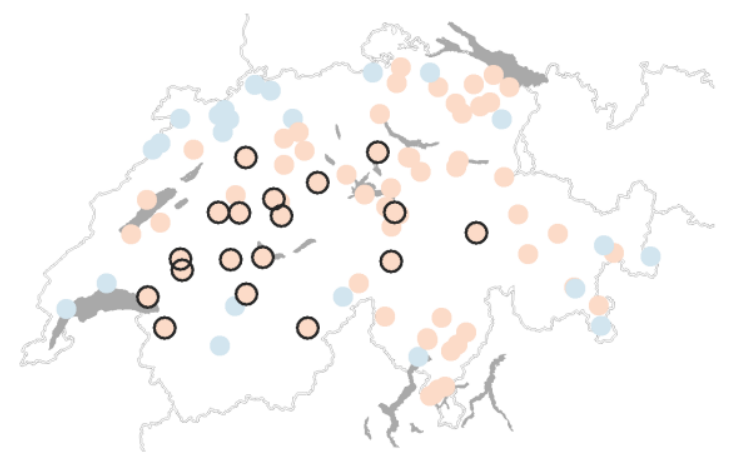

(b) MAM

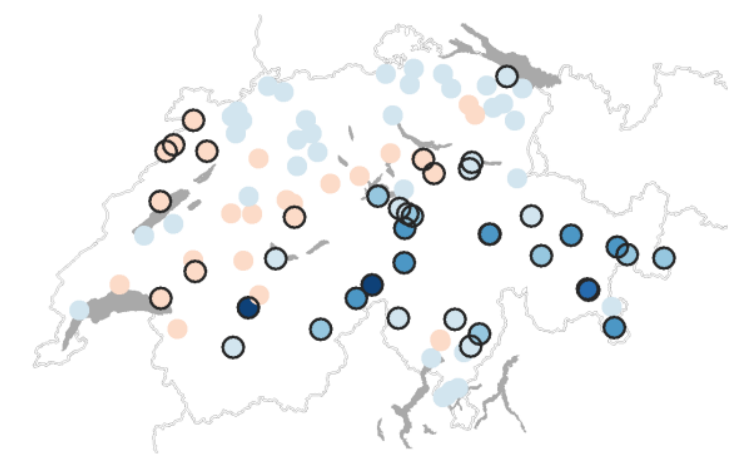

(d)

$$
\text { SON }
$$

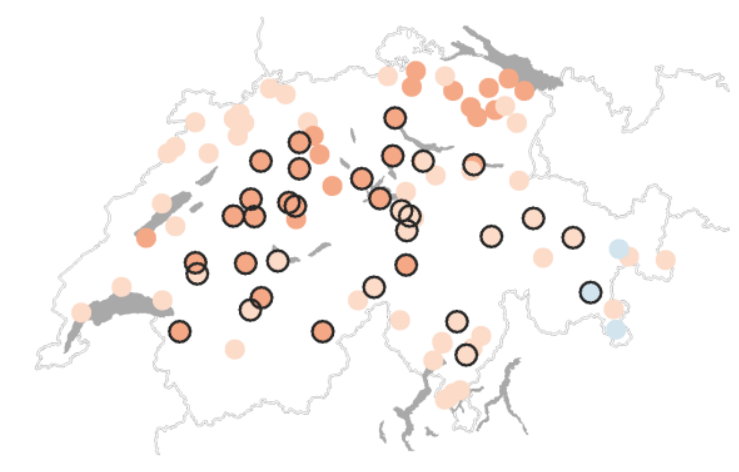

(\%)

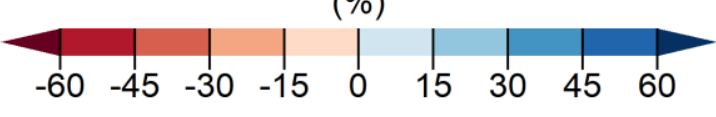

Figure S6: Multimodel median of seasonal and annual mean changes of runoff under RCP8.5 by 2045-2074 for winter (a), spring (b), summer (c), autumn (d), and annual means (e). Black circles indicate catchments whose direction of change agrees across at least $90 \%$ the models. 

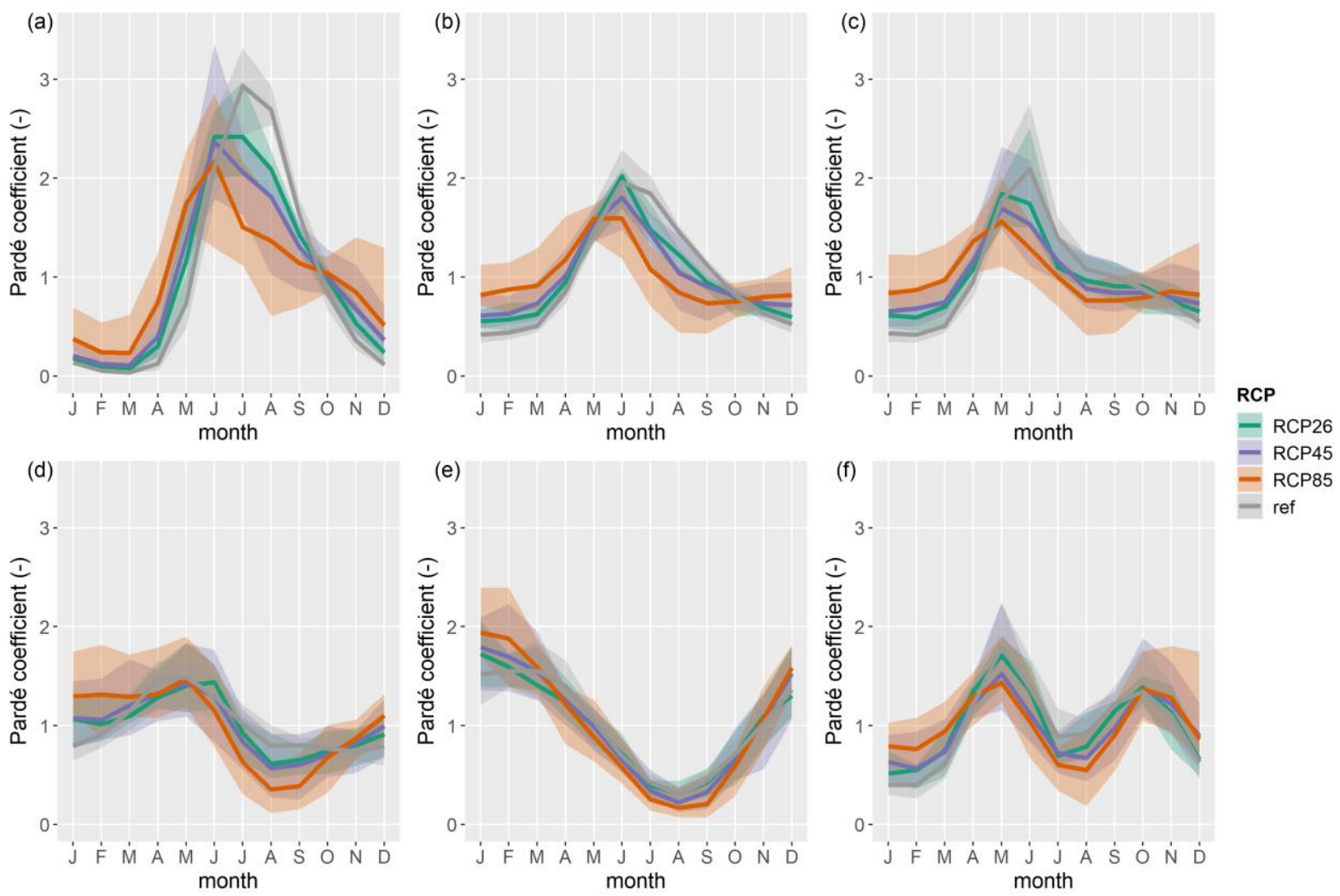

Figure S7: Pardé coefficients for the six representative catchments Rosegbach (a), Kander (b), Plessur (c), Emme (d), Venoge (e), and Verzasca (f). Thick lines represent the multi-model median for the reference period (grey), for 2070-2099under RCP2.6 (turquoise), for 2070-2099under RCP4.5 (blue), and for 2070-2099under RCP8.5 (orange). Shadings show the full model range for each RCP.
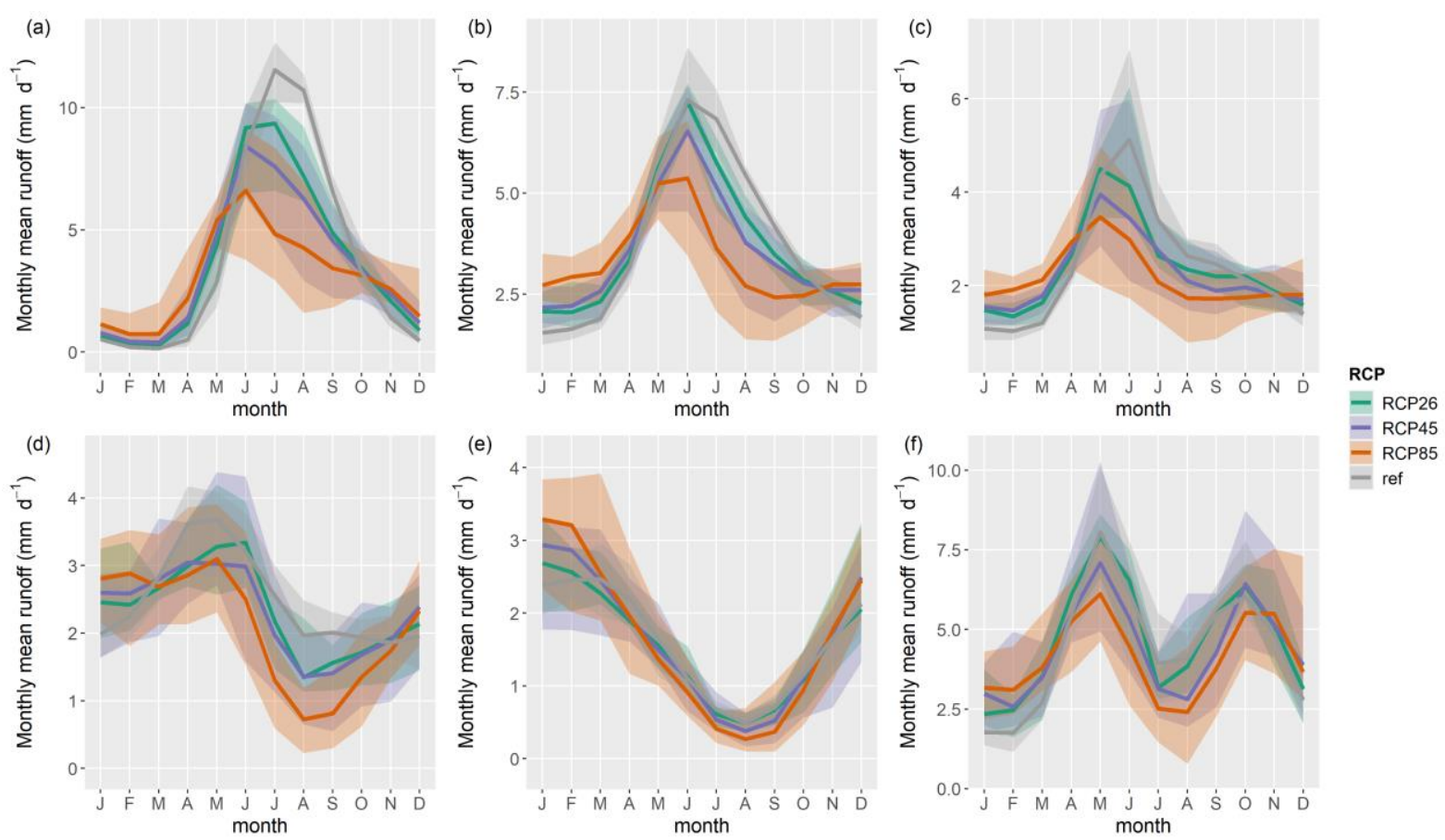

Figure S8: Runoff regimes for the six representative catchments Rosegbach (a), Kander (b), Plessur (c), Emme (d), Venoge (e), and Verzasca (f). Thick lines represent the multi-model median for the reference period (grey), for 2070-2099under RCP2.6 (turquoise), for 2070-2099under RCP4.5 (blue), and for 2070-2099under RCP8.5 (orange). Shadings show the full model range for each RCP. 

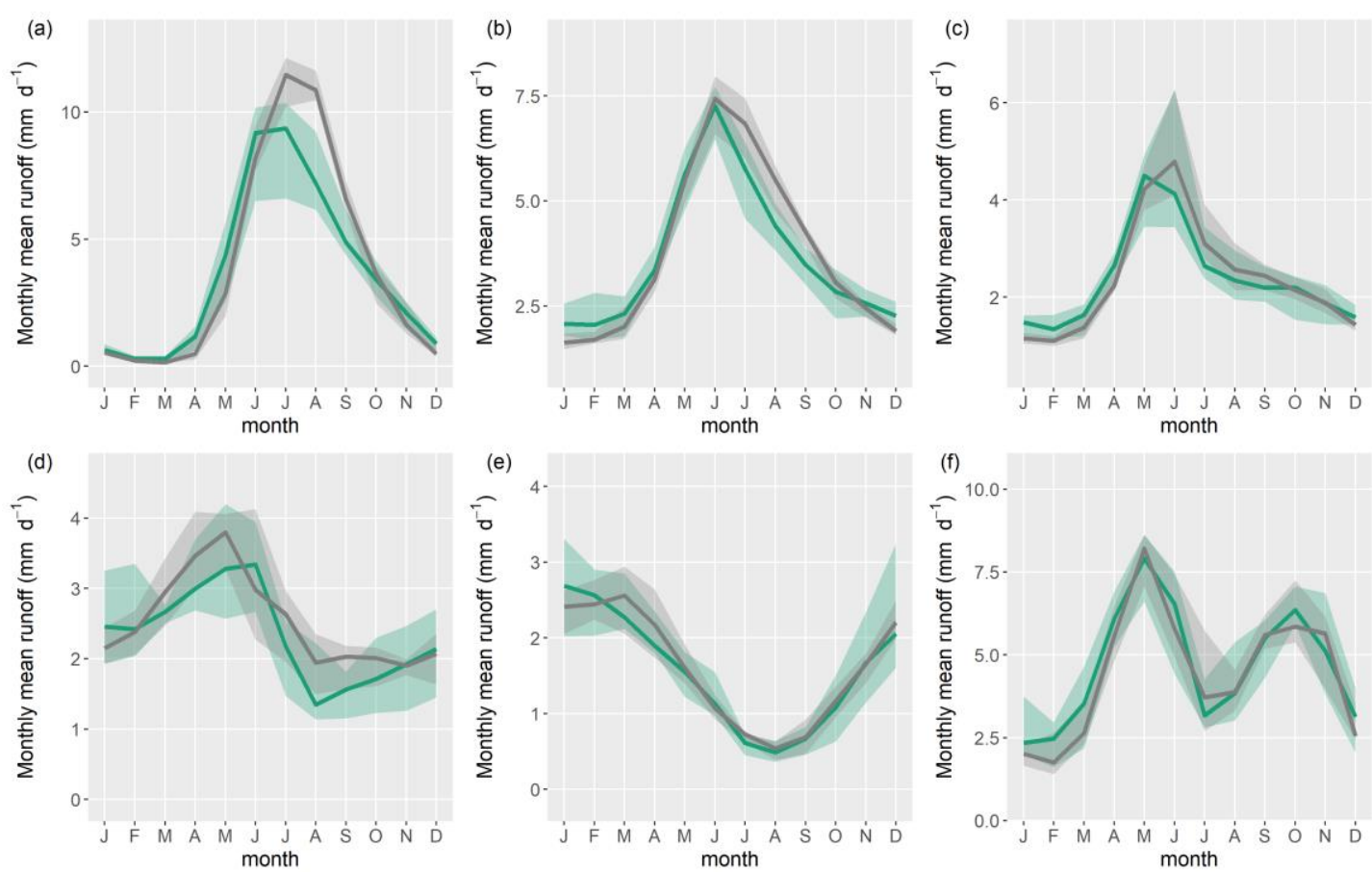

year
-2085

Figure S9: Runoff regimes for the six representative catchments Rosegbach (a), Kander (b), Plessur (c), Emme (d), Venoge (e), and Verzasca (f). Thick lines represent the multi-model median for the reference period (grey) and for 2070-2099under RCP2.6. Shadings show the full model range for each RCP.
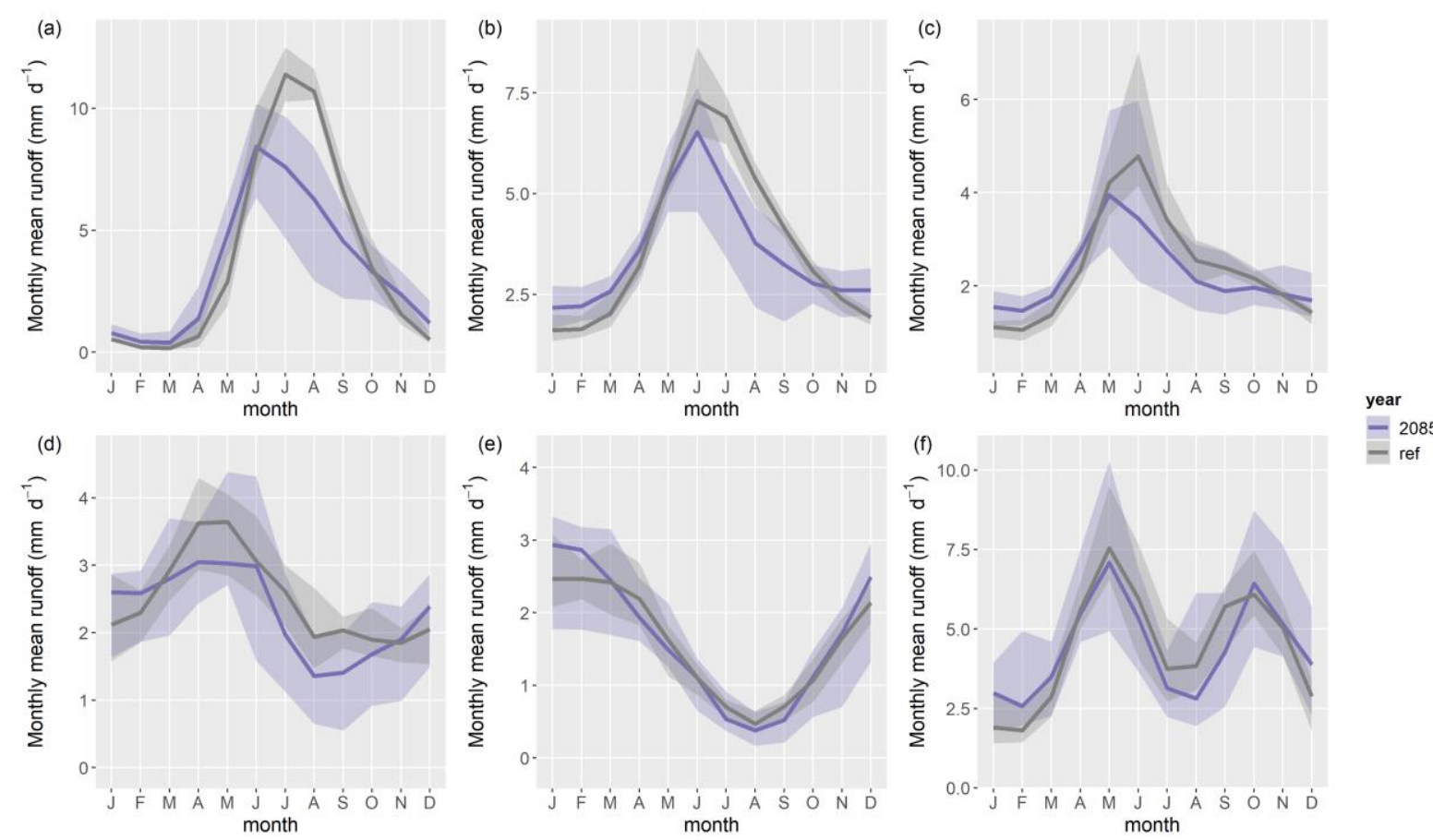

Figure S10: Runoff regimes for the six representative catchments Rosegbach (a), Kander (b), Plessur (c), Emme (d), Venoge (e), and Verzasca (f). Thick lines represent the multi-model median for the reference period (grey) and for 2070-2099 under RCP4.5. Shadings show the full model range for each RCP. 

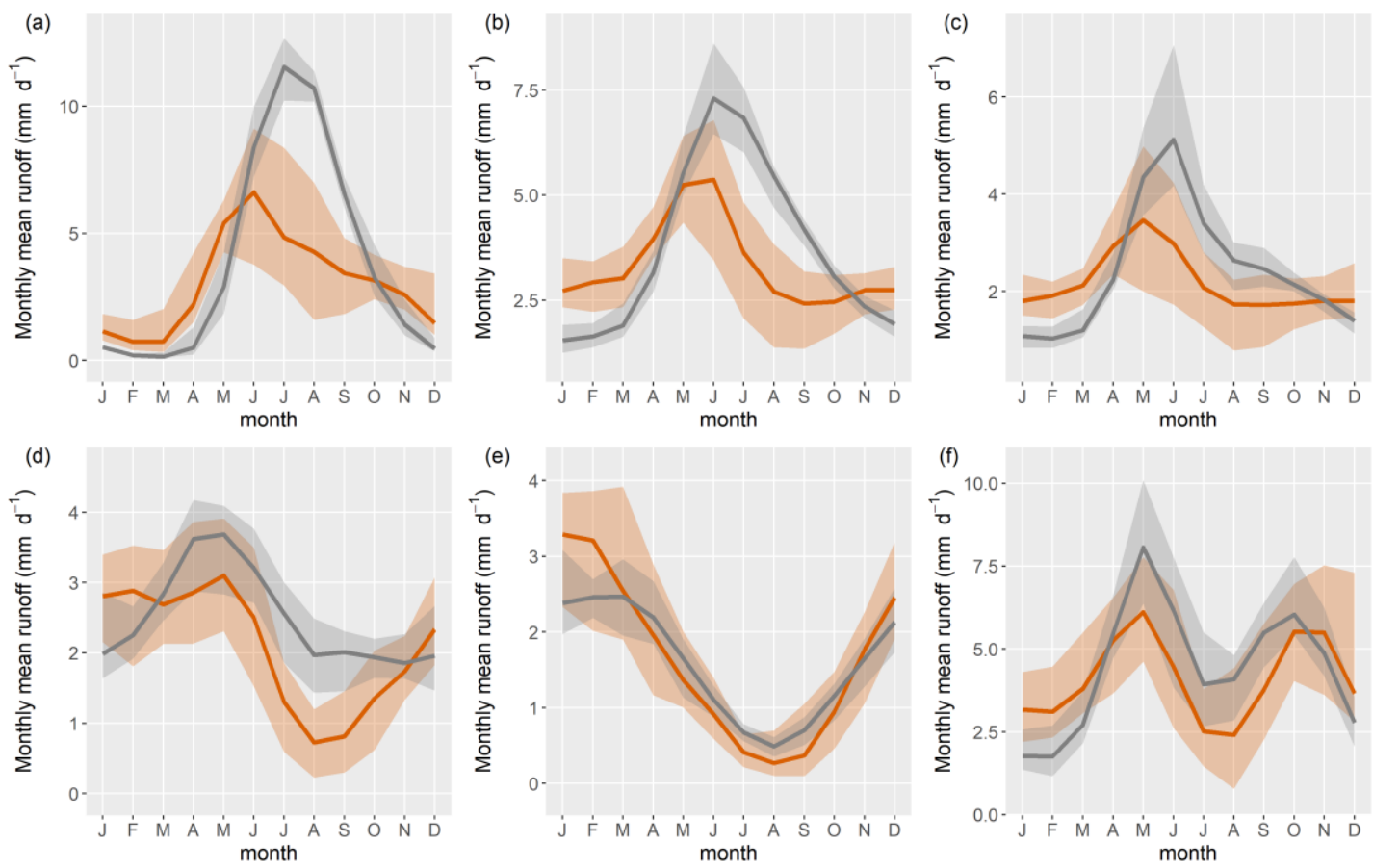

Figure S11: Runoff regimes for the six representative catchments Rosegbach (a), Kander (b), Plessur (c), Emme (d), Venoge (e), and Verzasca (f). Thick lines represent the multi-model median for the reference period (grey) and for 2070-2099 under RCP8.5. Shadings show the full model range for each RCP. 